\title{
Planothidium juandenovense sp. nov. (Bacillariophyta) from Juan de Nova (Scattered Islands, Mozambique Channel) and other tropical environments: A new addition to the Planothidium delicatulum complex
}

\author{
Catherine RiauX-Gobin ${ }^{1,2^{*}}$, Andrzej Witkowski ${ }^{3}$, Anton Igersheim ${ }^{4}$, Christopher \\ S. LobBan ${ }^{5}$, Adil Y. Al-HaNDAL ${ }^{6} \&$ Pierre COMPÈRe ${ }^{7} \uparrow$
}

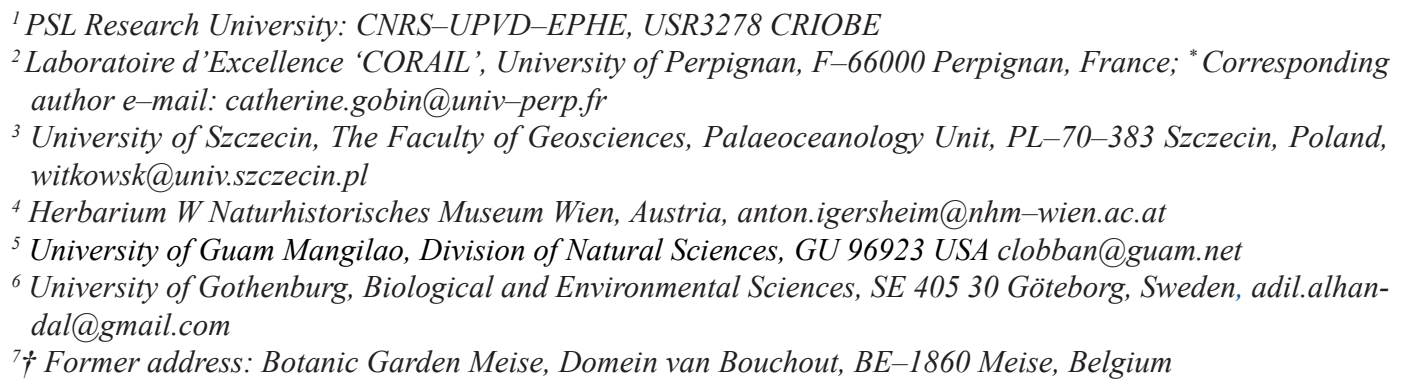

\begin{abstract}
Planothidium juandenovense sp. nov. (Bacillariophyta) is described from the marine tropical environments of Juan de Nova I. (Mozambique Channel), Rodrigues I. (Mascarene Archipelago) and from Guam (Northern Mariana Is., Pacific). This small and relatively rare taxon has short multiseriate striae on the sternum valve (SV), hooked raphe valve (RV) terminal raphe endings and no SV cavum or hoof-shaped area. This taxon has similarities with Planothidium delicatulum (KÜTZ.) Round et BukHT. and Planothidium septentrionale (Østrup) Round et BukHT. ex RUMrich et al., but also differences: e.g. a relatively narrow and rhombic SV sternum, void of areolae, with vestigial radiate structures and an uninterrupted marginal SV elevated crest or 'crista marginalis'. P. juandenovense sp. nov. is compared to some other Achnanthales with short SV striae. Cocconeis quarnerensis var. lanceolata JURILJ and Planothidium quarnerense f. rhombica (GIFFEN) comb. nov. may be close to our new taxon.
\end{abstract}

Key words: Planothidium, Achnanthales, tropical marine habitats, morphology, LM, SEM, allied taxa

\section{INTRODUCTION}

Achnanthes BORY 1822 is a widespread genus of heterovalvar, mostly small-celled taxa, that are often rare and difficult to study (RIAUX-GobIN et al. 2011). The taxonomic history is complicated. LANGE-BERTALOT \& KRAMMER (1989) distinguished two groups amongst Achnanthes sensu lato: one group based on Achnanthes microcephala (KÜTZ.) GRUNOW and A. minutissima KüTZ. and a second group based on Achnanthes lanceolata BRÉB. ex KÜTZ. More or less at the same time, Round et al. (1990) distinguished a group of taxa, with the generitype Achnanthes adnata BORY, pertaining to the genus Achnanthes sensu stricto, while the other taxa were grouped under Achnanthidium KüTz. 1844 (Round et al. 1990). As argued by BukHTIYARova \& Round (1996): 'leaving all Achnanthidium species in a single genus is not a satisfactory situation'. Thus, BukHTIYAROVA \& Round (1996) established the new genera Psammothidium BuKHT. et Round (see comments in MONNIER et al. 2007) and finally, Round \& BuKHTIYAROvA (1996) redefined the limits of the genus Achnanthidium and established four new genera: Rossithidium Round et BukHt., Planothidium Round et BukHt., Karayevia Round et BukHT. and Kolbesia Round et BukHT. The genus Kolbesia was subsequently subsumed into Karayevia (BukhtiYARova 2006). Otherwise, several genera were created to accommodate diverse difficult taxa (taxa needing appropriate generic classification): e.g. Platessa Lange-Bert., Crenotia Wojtal, Gliwiczia Kulikovskiy, Lange-Bert. et Witkowski, Astartiella WitKowski, LANGE-Bert. et Metzeltin (WitKowsKi 1998), Pauliella Round et BAsson and Lemnicola Round et BASSON (Round \& BASSON 1997), Scalariella 
RIAUX-Gob. (RIAUX-GobIN et al. 2012a), and some small marine taxa previously classified as 'Achnanthidium sensu lato’ (RIAUX-GobIN et al. 2010; RIAUX-Gobin et al. 2011), moved to Madinithidium WITKOWSKI, DESROSIERS et RiauX-Gob. (Desrosiers et al. 2014).

Planothidium, with Planothidium lanceolatum (BRÉB. ex Kütz.) LANGE-BERT. as generitype [type material examined with scanning electron microscope (SEM) by VAN DE VIJVER et al. (2013)], has some particular characteristics: e.g. multiseriate striae on both valves, internally thickened virgae and a SV 'cavum', hoof-mark or simple depression ('sinus') present in several species. Planothidium delicatulum (KüTZ.) Round et BuKHT. is one of the most common species in this genus, present in both marine and freshwater environments, with diverse varieties and forms grouped under the denomination Planothidium delicatulum 'complex' (i.e. 'Achnanthes delicatula-Komplex' in LANGE-BERTALOT \& KRAMMER 1989). See remarks about the complexity of this group (Discussion). The latter taxon lacks a cavum or sinus.
Planothidium includes small species particularly difficult to identify using light microscope and for which SEM is needed to produce a complete description (see MORALES 2006; Compère \& VAN DE ViJVER 2009; VAN DE ViJVer et al. 2013; BĄK \& LANGE-Bertalot 2014; Wetzel \& ECTOR 2014). All these papers refer to freshwater habitats. Marine and estuarine Planothidium are rarely investigated but there are many species in these habitats, especially in tropical and sub-tropical environments (RoviRA et al. 2011; RiauX-Gobin et al. 2012b; ÁlVAREZ-Blanco \& BLANCO 2013).

This paper describes a marine and relatively rare Planothidium, P. juandenovense RIAUX-GoB. et WITKOWsKI sp. nov., from tropical environments (Scattered Islands, Rodrigues Island, Indian Ocean and Guam, Western Pacific). The morphological characteristics of the new taxon are assessed using light (LM) and scanning electron (SEM) microscopy and compared with several allied taxa.
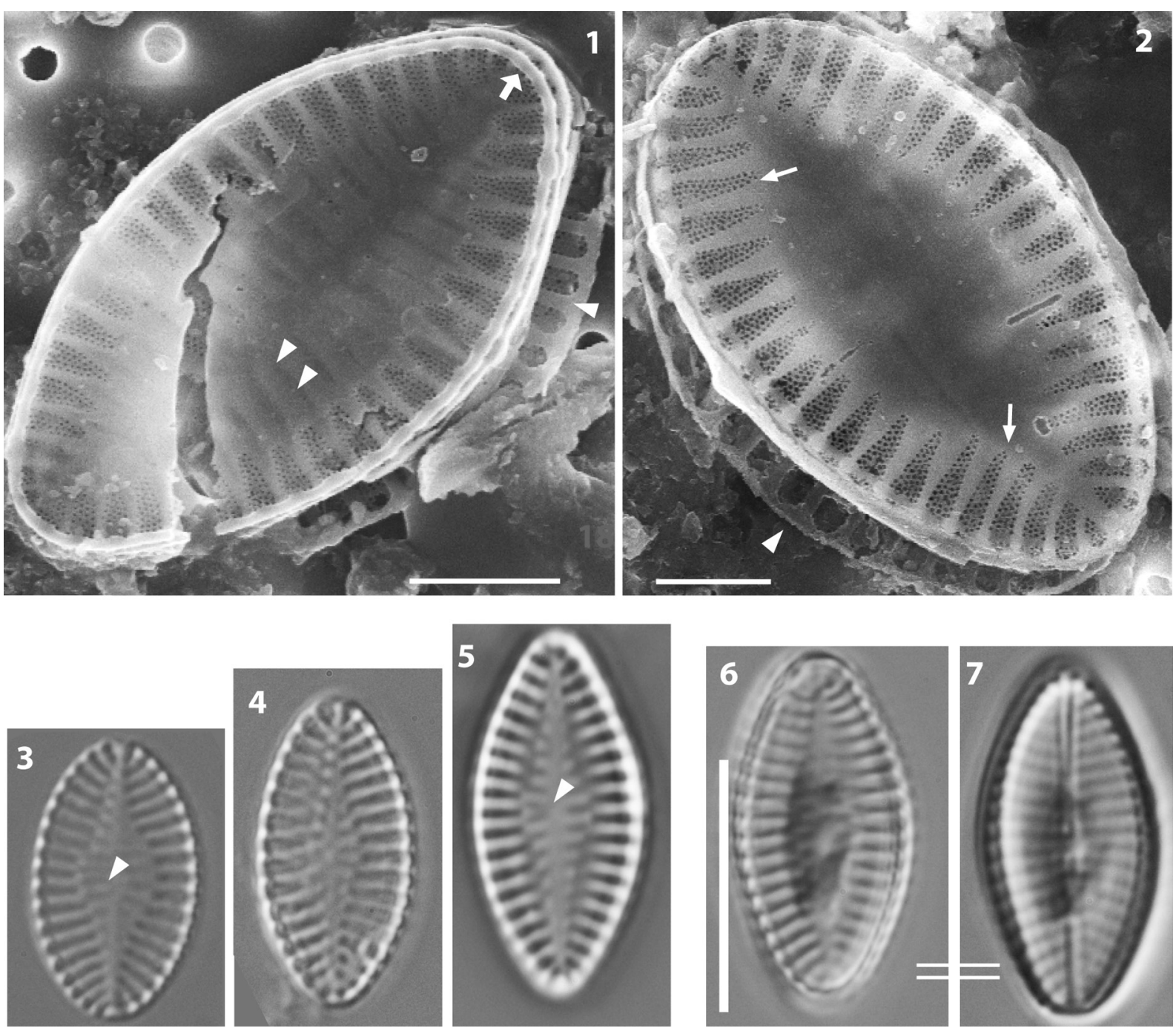

Figs 1-7. Planothidium juandenovense sp. nov. (SEM, figs 1-2; LM, Figs 3-7): (1, arrow) Complete frustules with the crista marginalis, (2, arrows) longer SV striae on apices and (1, twin arrowheads)vestigial structures on the SV, (1, 2, arrowhead) RV still in place. (3-5, arrowheads) SV in LM, with the rhombic SV sternum with radiate shadows, (6) SV and (7) RV of a complete frustule. Scale bars $10 \mu \mathrm{m}(3-7) ; 4 \mu \mathrm{m}(1) ; 3 \mu \mathrm{m}$ (2). 


\section{Materials ANd Methods}

Materials used in this study were from several sources: 1) Intertidal marine sediments and debris (coral and macroalgae) 'JDN2-macroalgae' were sampled from Juan de Nova Island (Scattered Islands, Indian Ocean, $17^{\circ} 02.798^{\prime} \mathrm{S}, 42^{\circ} 43.673^{\prime} \mathrm{E}$, TAAF 'EPARSES 2009' expedition; April 2009) and from Port Mathurin 'Port Mathurin 2' (Rodrigues Island, Mascarenes; $19^{\circ}$ $40.6^{\prime} \mathrm{S}, 63^{\circ} 25.0^{\prime} \mathrm{E}$; June 2007). The samples were preserved in formalin (10\% final concentration),

2) Intertidal coral reef sediments (coral debris, macroalgae) from Saluglula Pools, Inarajan, Guam, Mariana Islands, $13^{\circ} 16^{\prime} 17.38^{\prime \prime} \mathrm{N}, 144^{\circ} 44^{\prime} 52.36^{\prime \prime E}$; field collection number GU21AM-2, coll. C. Lobban and M. Schefter, 9 Oct. 2016, specimen in GUAM Diatom Herbarium, catalog number GUD004279, on SEM stub 965.

3) Grunow's collection in W: e.g. two GRUNOw-capsules collection of Amphora grevilleana GREGORY, with mica-slides W-1901/3921-3922, examined at ×40; sketches from GRUNOW's hand illustrating taxa in GRUNOw's 'Bilder-Sammlung' (W1901/3630, W-1901/3631); Grunow's accession book. A broken part of a slide covered with mica [GRUNOw-capsule collection of Navicula ovulum, from the locality '869' Porto Subzanski, Sansego I. (Susak, Croatia) Codium bursa \& Udotea, leg. Dr REICHARDT; W-1901/3162], permitted observations with SEM. 4) GifFEN's type raw material from Mahé (Seychelles Islands) was observed with SEM (i.e. a sample containing Cocconeis quarnerensis f. rhombica GIFFEN 1980).

For light microscopy (LM) examination, the samples were washed with distilled water to remove salts, treated with $30 \%$ $\mathrm{H}_{2} \mathrm{O}_{2}$ for $2 \mathrm{~h}$ at $70{ }^{\circ} \mathrm{C}$ to remove organic matter, rinsed several times in distilled water, alcohol-desiccated and mounted on glass slides using Naphrax ${ }^{\circledR}$. Diatom slides were examined with a Zeiss Axiophot 200, with differential interference contrast (DIC) optics and photographed with a Canon PowerShot EOS1000D digital camera (CRIOBE-USR 3278, Perpignan, France). The mica-slides from the GRUNOW's collection W were examined at $\times 40$, as recommended for the preservation of the slides.

For SEM examination of raw materials, samples were filtered through $1 \mu \mathrm{m}$ Nuclepore ${ }^{\circledR}$ filters and rinsed twice with deionised (milliQ) water to remove salts. Filters were air-dried and mounted onto aluminum stubs before coating with gold-palladium alloy (EMSCOP SC 500 sputter coater) and examined with a HiTACHI S-4500 SEM operated at $5 \mathrm{kV}$, calibrated with a Silicon grating TGX01 (C2M, Perpignan, France).

For SEM examination of the material contained on a broken part of the GRUNOw's slide 3162: after dissolving with toluene the material glued on the mounting medium, it was filtered through $0.2 \mu \mathrm{m}$ filter (Chromafil Xtra PTFE 20/13 from Macherey-Nagel GmbH \& Co. KG) and rinsed twice with ethanol, before being treated for SEM examination as described above.

We designate as holotype a LM slide (BM 101 810) showing specimens of the new taxon, with Fig. 4 as an holotype illustration. Nevertheless, the LM illustration does not provide a perfect overview of the taxa described in this report, particularly concerning the fine structure of the SV striae and SV crista marginalis (uninterrupted marginal elevated ridge or crest), as a result the scanning electron microscope (SEM) was essential for their description. Therefore, according to Article 40.5 of the International Code of Botanical Nomenclature (MCNeILL et al. 2012), and although it is a challenge to permanently preserve specimens on a stub, we designate as an isotype a stub (BM001223815) bearing several specimens showing diagnostic features of the new taxon. The slide and the stub were sent to NHM London.

Terminology used for the diatom frustules follows Anonymous (1975), Ross et al. (1979) and Round et al. (1990). As previously proposed, in particular by RIAUX-GoBIN et al. (2013), we designate the valve with a raphe as the raphe valve (RV) and the valve without a raphe as the sternum valve (SV). Standardized abbreviations and spellings of taxa authorities follow the IPNI. The morphometrics (Table 1) are based on the SEM examination of 29 specimens of $P$. juandenovense (from Juan de Nova, Europa, Rodrigues and Guam) and 10 specimens of $P$. cf. delicatulum (from Rodrigues Island).

\section{RESULTS}

Planothidium juandenovense RIAUX-GoB. et WITKOWSKI sp. nov. (Figs 1-20, Table 1, LM: 3-7, SEM: 1-2, 8-20) $\mathrm{n}=29 ; 7.5-19 \mu \mathrm{m}$ (av. $13.5 \pm 2$ ) long; 4-10 $\mu \mathrm{m}$ (av. $7 \pm 1.2$ ) wide. SV: (8)10-17 striae in $10 \mu \mathrm{m}$ (av. $14 \pm 1.7)$. RV: $11-16$ striae in $10 \mu \mathrm{m}$ (av. $14 \pm 1.7$ ) (Table 1).

Diagnosis: Valves small and elliptical, apices round to very slightly elongate (never protracted), rhombic SV sternum more or less narrow with transapical slits or markings, SV crista marginalis always present, groups of areolae on the short mantle, multiseriate short SV striae radiate throughout, $\mathrm{RV}$ striae rarely shorter on the centre on the valve.

Description (SEM): Valves small, elliptic, with round apices. SV: Valve face flat with SV sternum slightly concave (Fig. 8). SV striae radiate and short, regularly spaced, multiseriate (up to 5 rows of areolae near the margin), marginally interrupted by a well-developed and uninterrupted crista marginalis (Figs 8-10). The striae terminate abruptly near the wide sternum in specimens from the Mascarenes (Figs 9,11) or extend in one row of areolae in Juan de Nova specimens (Figs 10, 14). On the elliptic and wide SV sternum, one slit-marking (sometimes two) occur as an extension of each virga, resembling radial vestigial structures (Fig. 10, arrowheads, Fig. 11, arrowhead). In LM, these vestigial structures appear as shadows on the sternum, alternating with the marginal striae (Figs 3-5). In internal view, the virgae are elevated, giving each stria the appearance of a loculus (Fig. 24). One row of grouped areolae on the short SV mantle (Fig. 9). Broad cingulum composed of open bands (Figs 9, arrowhead, Fig. 12, framed arrowhead). Sternum valve valvocopula (SVVC) not observed. RV: Valve face strongly convex (Fig. 16). Striae multiseriate, radiate, regularly spaced, virgae narrow (Figs 13, 15). Sometimes one shorter stria on one side of the valve (Fig. 15). In internal view the virgae and axial area are elevated (Fig. 17). Central raphe endings well apart, round, internally coaxial, central area reduced (Fig. 19). Terminal raphe endings hooked in the same direction (Fig. 15). Helictoglossae straight and small (Fig. 18, arrowhead). Raphe valve valvocopula (RVVC) with 


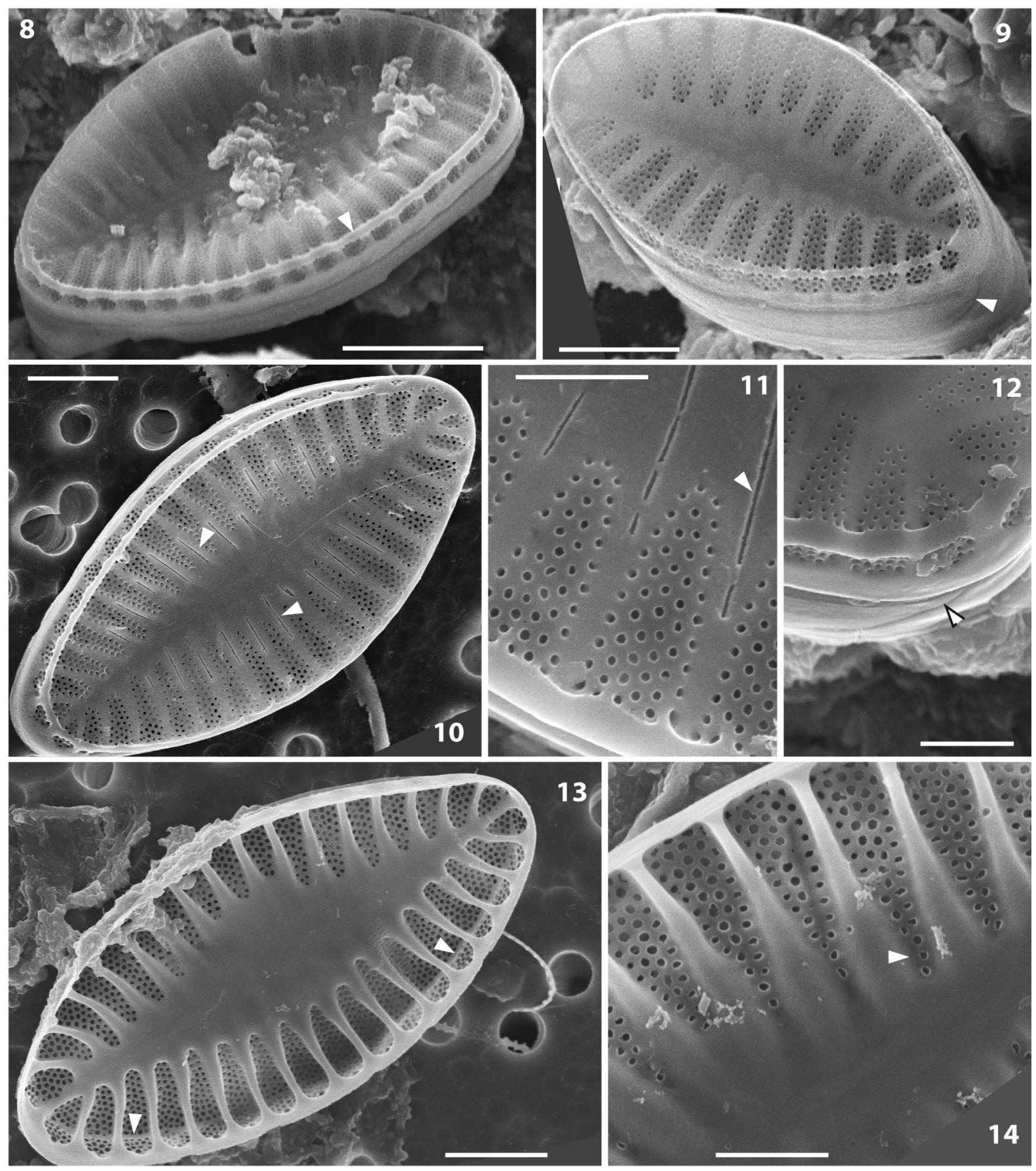

Figs 8-14. Planothidium juandenovense sp. nov. (SEM): (8, arrowhead) SV with the uninterrupted crista marginalis and depressed SV sternum with particular structures. (9, arrowhead) High cingulum with open bands and (9) groups of areolae on the short mantle. (10, 11 arrowheads, individual from Mascarenes) Slits 'vestigial structures' between each stria (on each virga), (12, framed arrowhead) open cingular bands and (12) strong crista marginalis. (13, arrowheads) SV in internal view with sort of loculi, note the position of the crista marginalis. (14, arrowhead, individual from Juan de Nova Island) SV striae prolonged but a row of single areolae. Scale bars $5 \mu \mathrm{m}(8) ; 2 \mu \mathrm{m}(9-10,13) ; 1 \mu \mathrm{m}(11-12,14)$.

possible short fimbriae (Fig. 18 arrow, to be confirmed). Holotype designated here: BM 101810 housed in BM, made from the sample 'JDN2-macroalgae'

Holotype illustration: Fig. 4.

Isotypes: Stub 2-280214 JDN2-macroalgae housed in BM (BM001223815), slide JDN2 in C. R.-G. collection (USR 3278, CRIOBE, F-Perpignan) and slides 16491-16492 in A.W. SZCZ collection (Palaeoceanology Unit, PL-Szczecin, Poland).
Type locality: Juan de Nova, sample 'JDN2-macroalgae' (26 April 2009). $17^{\circ} 02.798^{\prime} \mathrm{S}, 42^{\circ} 43.673^{\prime} \mathrm{E}$.

Etymology: The epithet juandenovense refers to Juan de Nova Island from where the RV of the taxon was first observed.

Additional materials examined: Rodrigues, sample 'Port Mathurin 2' (in C. R.-G. collection, USR 3278, CRIOBE, F-Perpignan); Guam, sample GU21AM-2. 

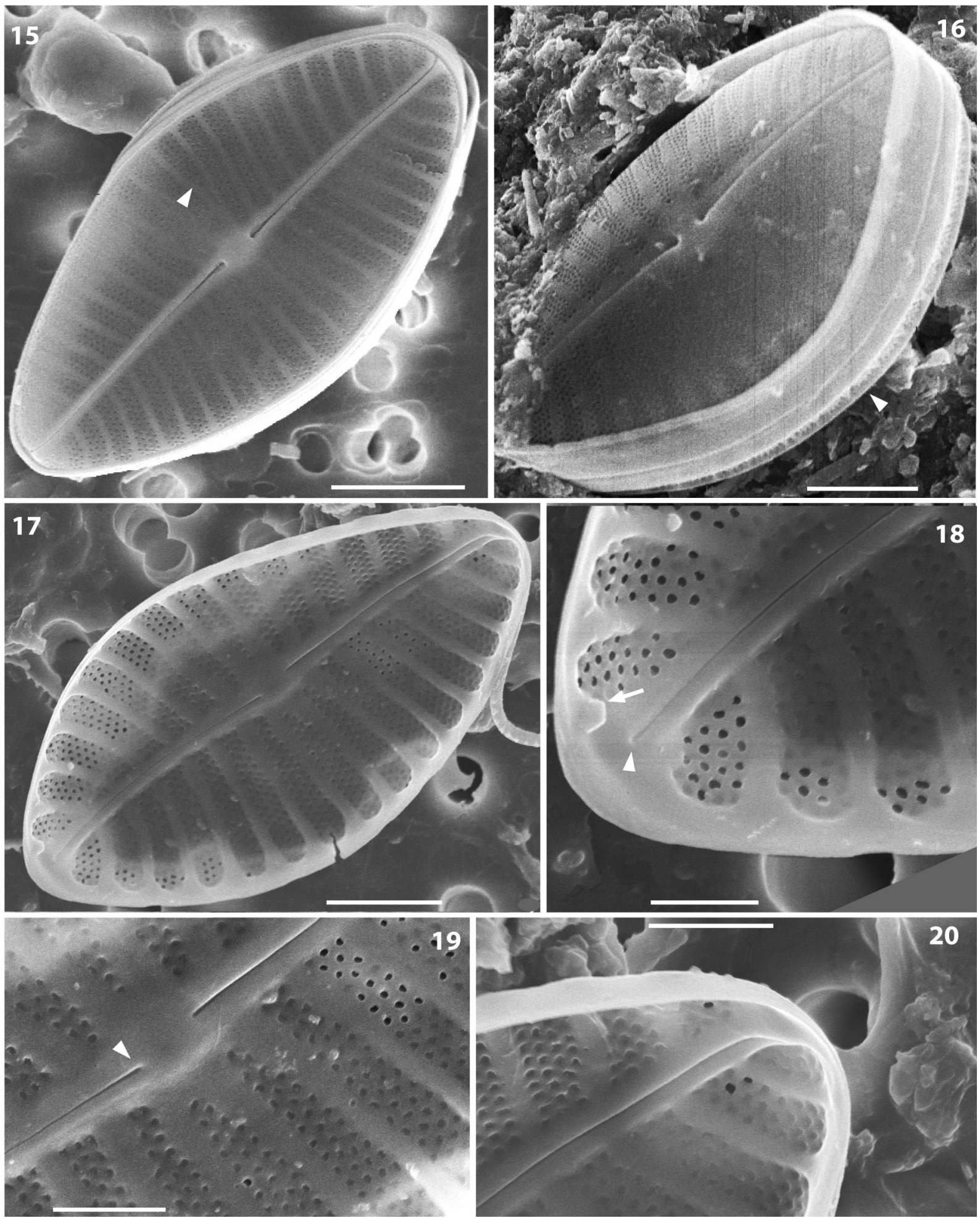

Figs 15-20. Planothidium juandenovense sp. nov. (SEM): (15, arrowhead) RV with regularly spaced striae, narrow virgae and a marginal shorter stria. (16, arrowhead) Complete frustule in cingular view, with the convex SV with strong central raphe endings and the SV crista marginalis. (17) RV in internal view, with the straight raphe, and elevated virgae and axial area. (18, arrow) Possible RVVC short fimbriae and low and straight helictogloss (18, arrowhead). RV central area in internal view with the straight proximal raphe endings (18, arrowhead). (20) RV apex in internal view, with the subtle helictogloss. Scale bars $3 \mu \mathrm{m}$ (15-16); $2 \mu \mathrm{m}(17) ; 1 \mu \mathrm{m}(18-20)$.

Remarks: Planothidium juandenovense sp. nov. is rare and its valvocopulae system is not yet elucidated, but the SV structure (Figs 9-10, Table 1) is different from that of Planothidium cf. delicatulum from the Indian
Ocean (samples from Rodrigues, Figs 21-24, Table 1): e.g., the apices of the new taxon are not protracted, nor capitate, the striae of both valves are slightly denser and the virgae on both valves are narrower than in 


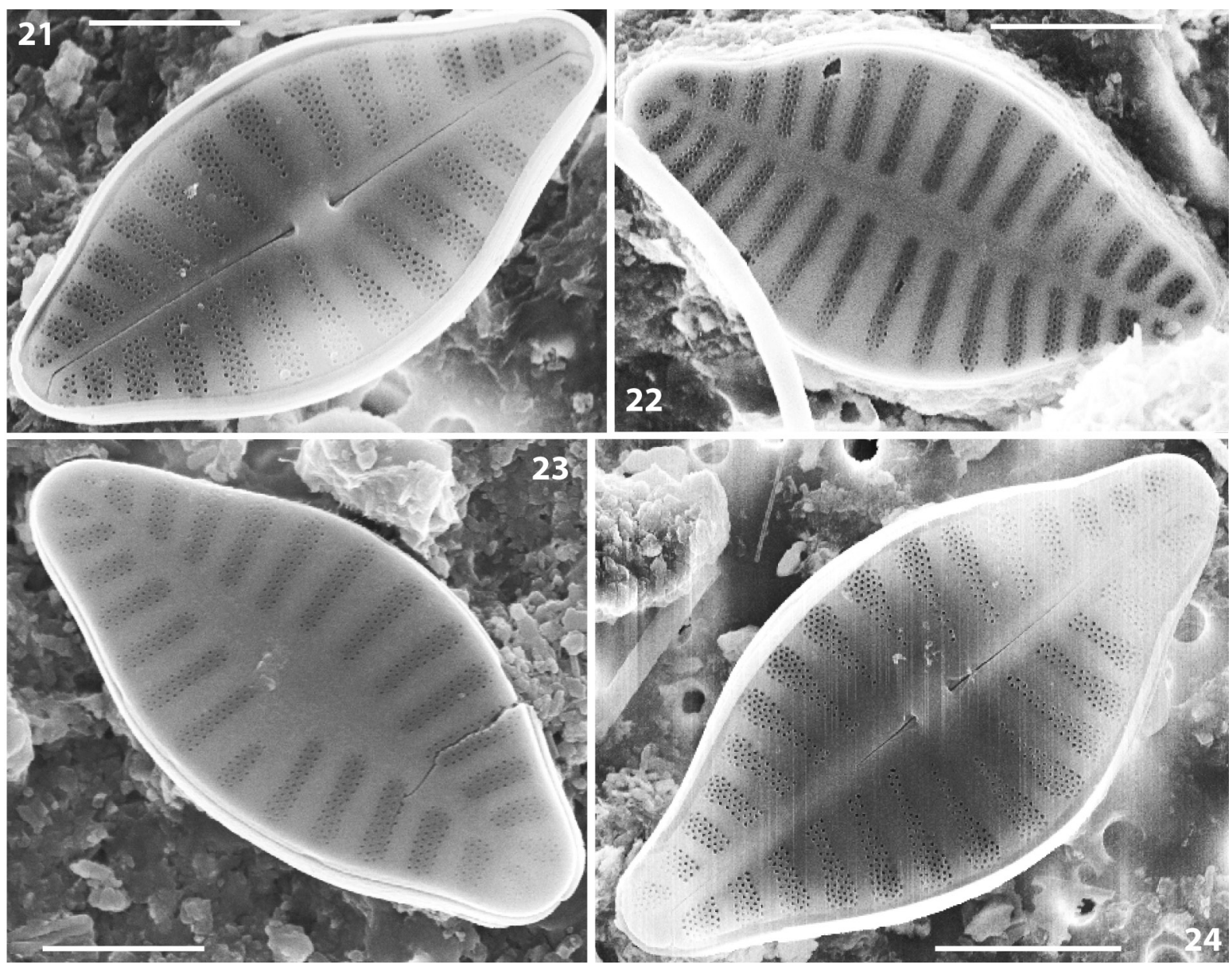

Figs 21-24. Planothidium cf. delicatulum (SEM, from Rodrigues I.): (21) RV with large virgae and central area delineated by two shorter striae. (22) SV with a relatively narrow sternum. (23) SV with an elliptic sternum and a shorter stria on one side. (24) RV with spathulate proximal raphe endings. Scale bars $5 \mu \mathrm{m}$ (22); $4 \mu \mathrm{m}$ (24); $3 \mu \mathrm{m}(21,23)$.

$P$. cf. delicatulum. In internal view, the P. juandenovense $\mathrm{SV}$ virgae are elevated and delineate short marginal chambers (cf. Figs 13-14). Furthermore the uninterrupted SV crista marginalis (see above) is not present in $P$. cf. delicatulum. See the following remarks about Planothidium delicatulum sensu stricto. P. juandenovense sp. nov. has some similarities with $P$. quarnerense (Grunow) WitKowski, Lange-Bert. et Metzeltin and allied taxa (see below). The illustrations in SAR et al. (2003: figs 7-8) may possibly refer to Planothidium juandenovense. The new taxon was first found in the Indian Ocean and Mozambique Channel, but recent investigations proved its presence in the Pacific Ocean (i.e., Guam), expanding its biogeography. This taxon is probably pantropical.

\section{Discussion}

Planothidium juandenovense has similarities to other Achnanthales with multiseriate SV striae. We examine the similarities with, 1) P. delicatulum (sensu stricto and sensu lato), 2) some Achnanthidiaceae D.G.MANN with short multiseriate SV striae, in Platessa and Planothidium, and finally 3) $P$. quarnerense and allied taxa.

\section{Planothidium delicatulum sensu stricto, history}

We note that a comparison of Planothidium juandenovense with $P$. delicatulum sensu stricto is hardly possible since KÜTZING's description and illustrations are so poor that it is difficult to reliably identify the species based on KüTZING's drawings. Nevertheless, we can note that KüTZING's drawings (KüTZING 1844: as Achnanthidium delicatulum KÜTZ., p. 75, pl. 3, fig. 21 reproduced in Fig. 25 ) evoke that the pervalvar bent frustule is round-elliptical, with clearly protracted apices, with a small round central area. The illustration of Achnanthes delicatula (KüTZ.) Grunow in Van HeurcK (1880-1885; pl. 27, figs 3-4, reproduced in Fig. 26) also clearly shows protracted apices. A 'neotype', slide BM 26545 (from VAN HeURCK's Types des Synopsis nr 234) was designated by LANGE-BERTALOT \& RUPPEL (1980; pl. 1, figs 28-31) but this 'neotype' (see also LANGE-BERTALOT \& KRAMMER 1989; pl. 80, figs 1-5) was rightly challenged by ÁlVAREZ-BLANCO \& BLANCO (2013): since a part of the original material, i.e. the illustration, is still available, 


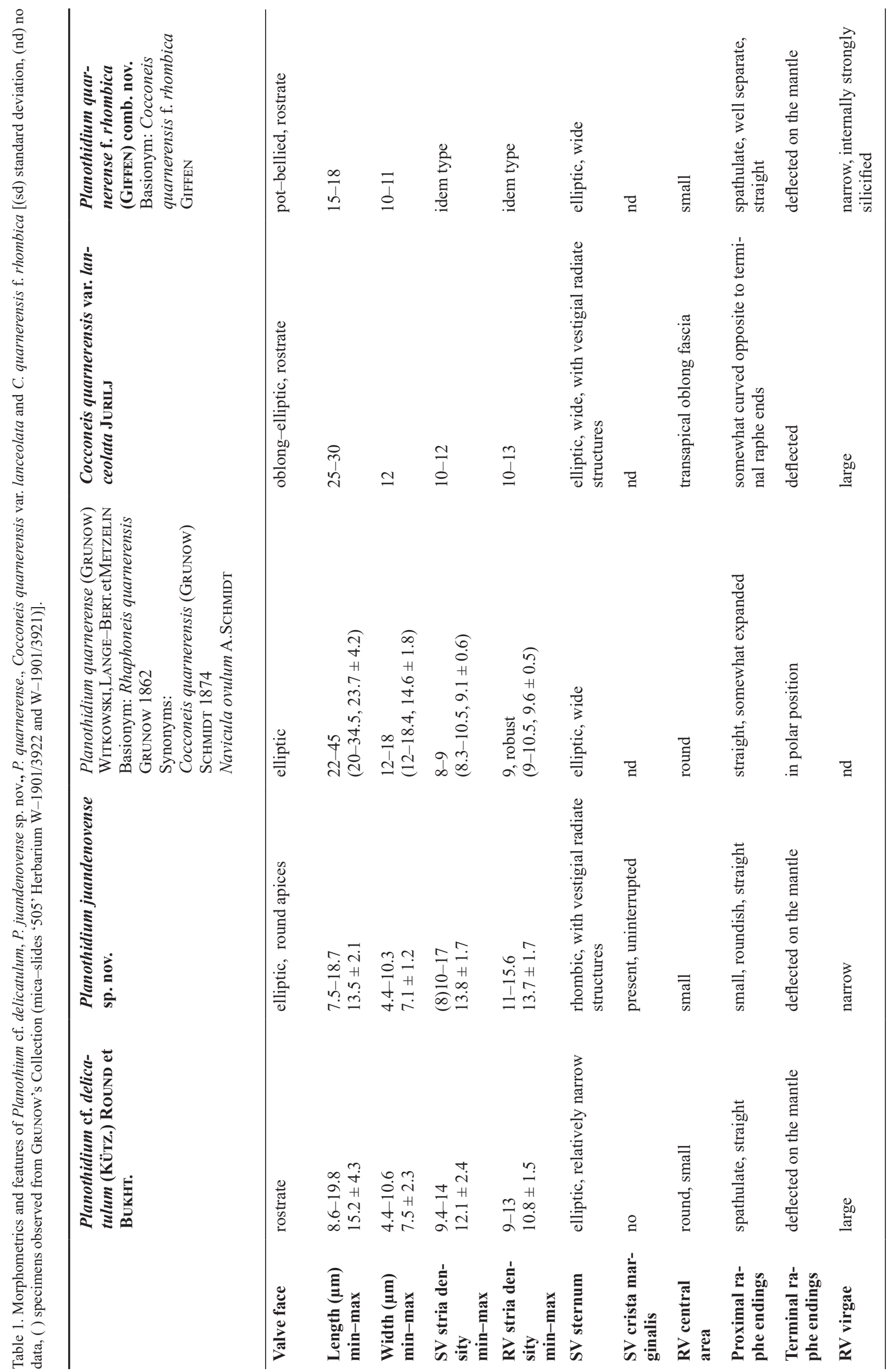




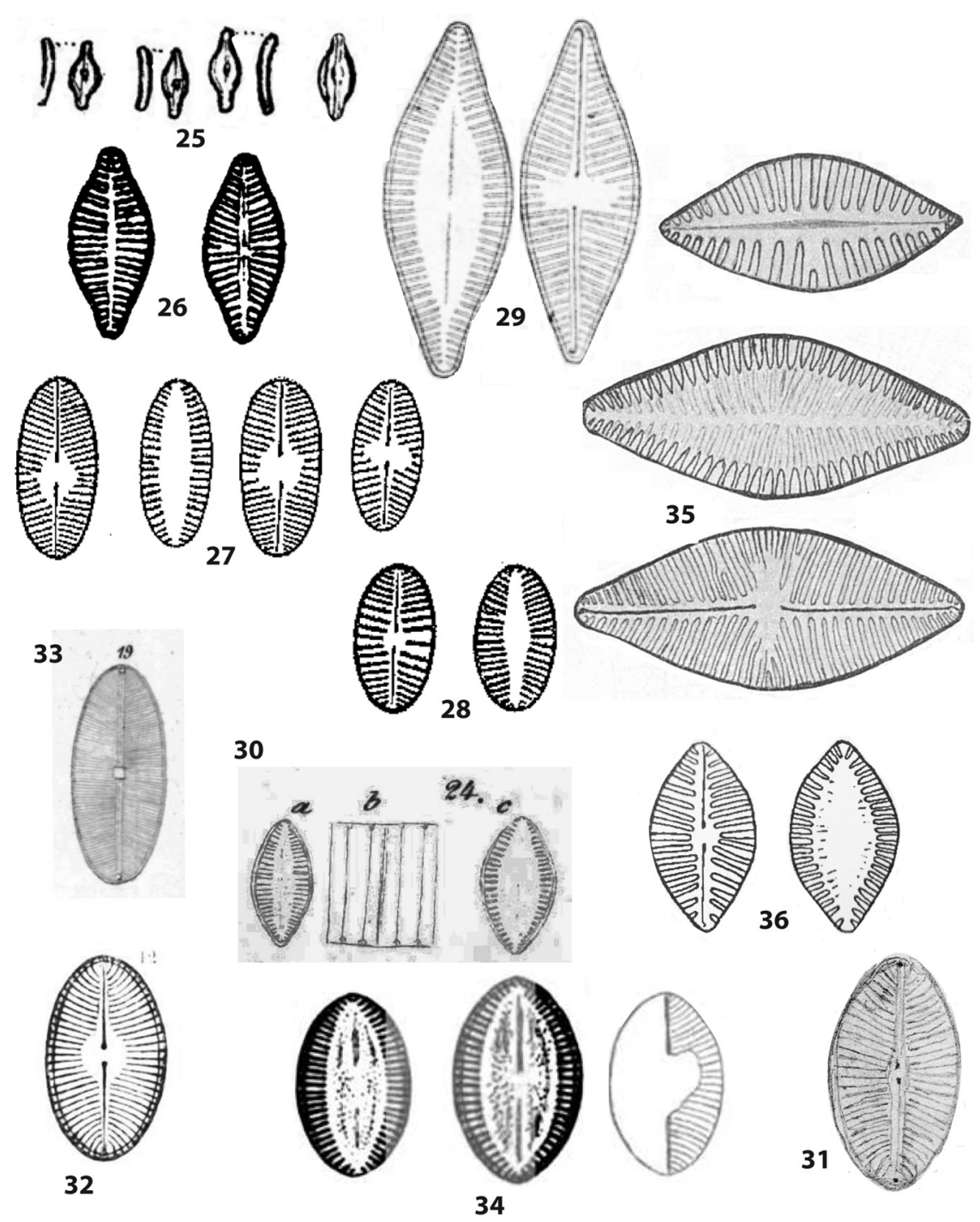

Figs 25-36. Reproduced from original figures: (25) Achnanthidium delicatulum KüTz. (1844; pl. 3, fig. 21), (26) Achnanthes delicatula (KüTZ.) Grunow in VAN HeurcK (1880-1885; pl. 27, figs 3-4), (27) Platessa hustedtii (KrassKe) LANGE-Bert. (Basionym: Cocconeis hustedtii KrassKe, illustrated in ManguIN 1952: fig. 27), (28) Achnanthes hauckiana Grunow var. elliptica SchUlZ, f. fossilis in MANGUIN (1952; fig. 29), (29) Planothidium holstii (Cleve) Lange-Bert. (Basionym Achnanthes holstii Cleve 1881; 13, pl. 16: figs 6-7), (30) Raphoneis(?) quarnerensis Grunow [1862; pl. 4, fig. 24a,(b),c], (31) Cocconeis quarnerensis (with GruNOw no. 869.6) sketch in Grunow's 'Bilder-Sammlung' (Acqu. 1901/3630), (32) Navicula ovulum Grunow in Schmidt (1874; pl. 2, fig. 12), (33) Navicula ovulum Grunow (1860; pl. 1, fig. 19), (34) Cocconeis quarnerensis Grunow in Schmidt (1874; pl. 3, fig. 15-16), (35) Cocconeis quarnerensis var. lanceolata JURILJ (1957; pl. 16, figs 4a,b,c), (36) Cocconeis quarnerensis f. rhombica GiFFen (1980; figs 13-14). Figures not at the same scale. 

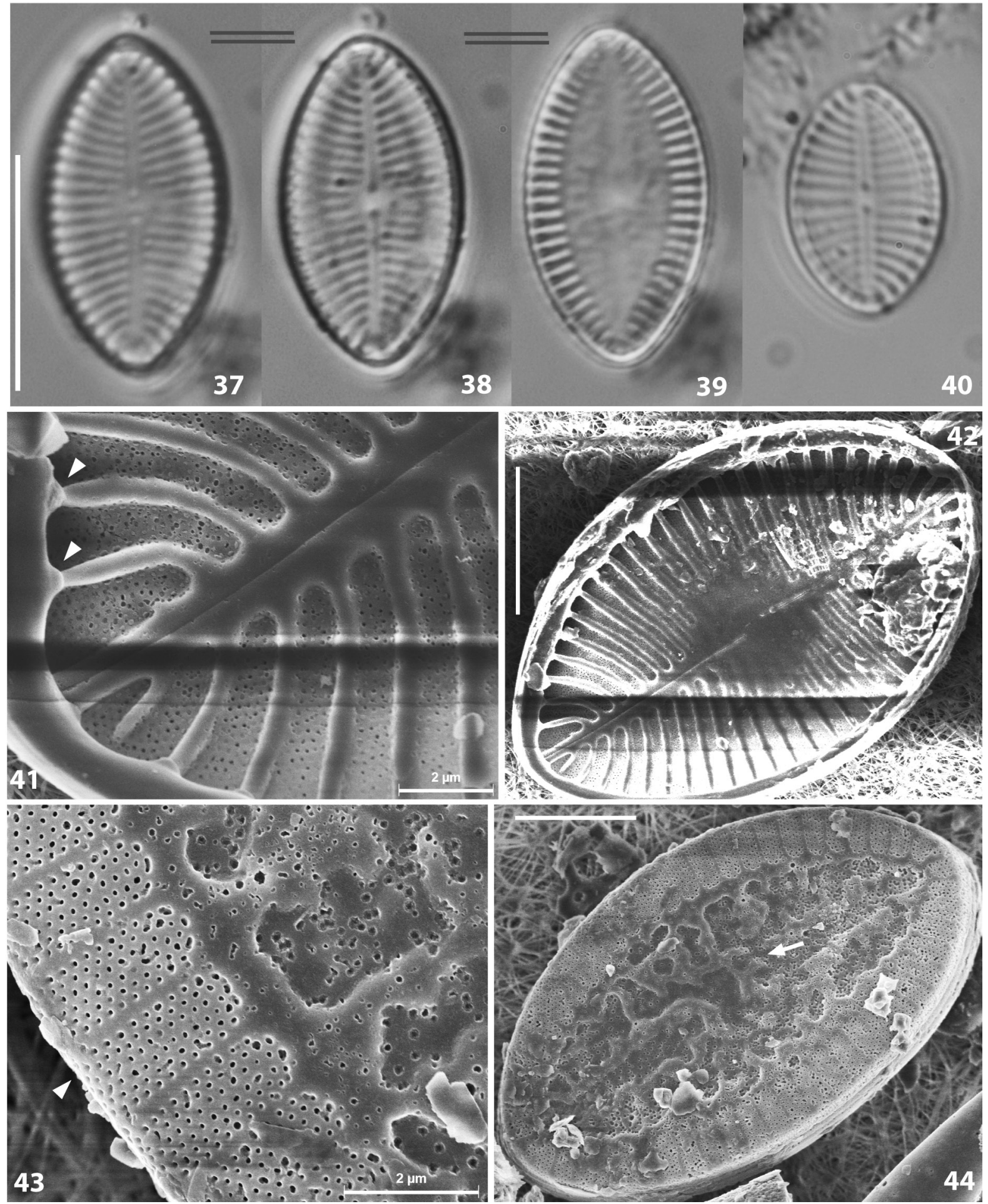

Figs 37-44. Raphoneis quarnerensis GrUNOw from '505' slides-micas W-1901/3921-3922 (Grunow-capsule collection of Amphora grevilleana): (37-40) note the large elliptical SV sternum with a granular aspect (39) and the short and regular SV striae, Navicula ovulum GRUNOw from the broken ' 869 ' slide-mica W-1901/3162 (GRUNow-capsule collection of Navicula ovulum), (41-42) with a large RV central area (42) and the RVVC (RV valvocopula) with short-digit fimbriae (41, arrowheads), Raphoneis quarnerensis from the broken ' 869 ' slide-mica W-1901/3162 (GRUNOW-capsule collection of Navicula ovulum), with short multiseriate striae, no crista marginalis (Fig. 43, arrowhead) and a large sternum with granular structure (Fig. 44, arrow). Scale bars $20 \mu \mathrm{m}$ (37-40); $10 \mu \mathrm{m}$ (42); $6 \mu \mathrm{m}(44) ; 2 \mu \mathrm{m}(41,43)$.

it was mandatory to designate a lectotype rather than a neotype (McNeILL et al. 2012; art. 9.12, 9.13) and moreover, the proposed 'neotype' was in serious morphological conflict with the protologue (MCNeILL et al. 2012; art. 9.19). Álvarez-Blanco \& Blanco (2013) did not designate a lectotype so that the name Achnanthes delicatula remains undefined. It can be noted that LANGEBERTALOT \& KRAMMER (1989) themselves show some hesitation in illustrating Achnanthes delicatula (KÜTZ.) GrunOw ssp. delicatula since they give the comment: 

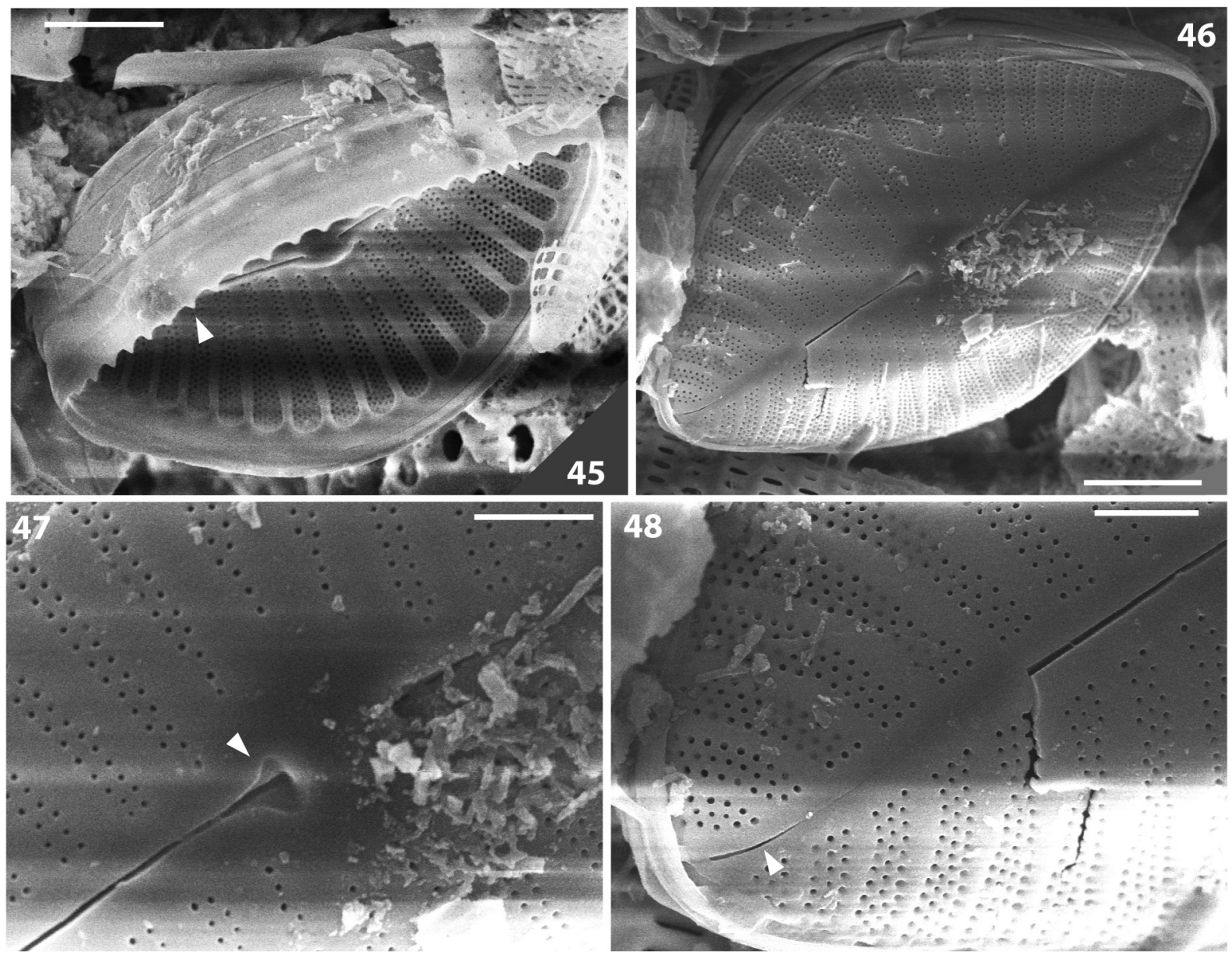

Figs 45-48. Planothidium quarnerense f. rhombica (GIFFEN) WITKOwSKI et RiAUX-Gob. comb. nov. (SEM, from GifFeN's type raw material from Seychelles Is.): (45) RV internal side, with multiseriate striae and oval reduce and strongly silicified central area. Note the RVVC (RV valvocopula) with short-digit fimbriae (45, arrowhead). (46) External view of a RV, with characteristic pot-billed shape and protracted apices. (47) Details of the external RV, with spathulate proximal raphe ending and discreet central area and terminal raphe fissures deflected on the mantle (48). Scale bars $3 \mu \mathrm{m}$ (45-46); $1 \mu \mathrm{m}(47-48)$.

'heterogene Sippen, ergo 'sensu lato'. Finally, concerning Planothidium delicatulum sensu stricto, it can be noted that KüTZING's raw material from Wangerooge was found by Pierre COMPÈRE and Bart VAN DE VIJVER in the VAN HeURCK collection (BR, Botanic garden, Meise). This material could belong to KüTZING's original material. In LM, the latter material clearly shows protracted specimens (Bart VAN DE VIJVER, comm. pers.) matching the original drawings by KüTZING (see above remarks).

\section{Planothidium delicatulum sensu lato}

Several other taxa can be compared to Planothidium juandenovense: e.g., P. septentrionale (Østrup) Round et BuKHT. ex Rumrich et al. (2000) (Synonym: Achnantheiopsis septentrionalis (Østrup) LANGE-BERT.); Achnanthes delicatula ssp. septentrionalis (Østrup) LANGE-BERT.) as illustrated in LANGE-BERTALOT \& KRAMMER (1989; 46 , pl. 82, figs 1-24) with characteristics close to those of $P$. delicatulum as illustrated by the same authors, but with a more rhombic valve shape and less protracted apices; P. australe (MANGUIN) Le CoHU (2005; pl. 5, figs 56-61) (Basionym: Achnanthes delicatula var. australis
MANGUiN in BourRelly \& MANGUIN (1954; 20, pl. 2, fig. 18 a,b) with extremely protracted apices, from which a dubious RV external SEM view is proposed under Achnantheiopsis robusta in LANGE-BERTALOT (1997; fig. 21, as a possible synonym of Achnanthes delicatula var. robusta Hust., see illustration in SimONSEN 1987; pl. 241, figs 31-32); P. engelbrechtii (CHOLNOKY) Round et BUKHT. (see identification and typification in COMPÈre \& VAN DE VIJVER 2009) and P. galaicum (Álvarez-Blanco \& BLANCO 2013). However, in contrast to all these taxa, P. juandenovense has an elliptic shape and apices round to very slightly elongate (never protracted), and systematically exhibits a more or less narrow rhombic SV sternum, a continuous and robust SV crista marginalis, and groups of areolae on the short mantle; the multiseriate short SV striae are radiate throughout valve and the $\mathrm{RV}$ striae are rarely shorter in the centre on the valve.

\section{Achnanthidiaceae D.G.MANN with short multiseriate SV striae (i.e., Platessa and Planothidium)}

Numerous Achnanthidiaceae D.G.MANN taxa, generally small and from freshwater environments, have short bi- to 
multiseriate SV striae (see LANGE-BERTALOT \& KRAMMER 1989; Potapova 2011). In LM, the SV of Platessa hustedtii (KRASSKe) LANGE-Bert. (Basionym: Cocconeis hustedtii KRASSKE, see MANGUIN 1952; fig. 27 reproduced in Fig. 27) can be confused with the SV of our new taxon, but $P$. hustedtii has a RV completely different from that of the new taxon (see SEM illustration in PotaPova 2011) and it is a freshwater species. Planothidium hauckianum (GRUNOw) Round et BuKHT. 1996 [Basionym: Achnanthes hauckiana GRUNOw in Cleve \& GRUNOW 1880; Synonyms: Achnanthes hauckii GRUNOW (in VAN HeurcK 1880-1885; pl. 27, figs 14-15); Achnanthes delicatula ssp. hauckiana (GRUNOW) LANGE-BERT. et RuPPEL (1980; pl. 1, figs 1-18; LANGE-BERTALOT \& KRAMmer 1989; Lectotype, coll. Grunow 1238, Rekaquellen bei Triest/Jugoslawien, pl. 87, figs 14-23); Achnanthidium hauckianum (GRUNOw) CZARN. (1994)] is oblong-elliptical, with a SV showing a sternum wider than that in Planothidium delicatulum, multiseriate striae (LANGe-Bertalot \& RupPel 1980; pl. 8, figs 268a-c and LANGE-Bertalot \& KrAmmer 1989; pl. 90, figs 5-6) and two SV (and RV?) striae more distant on one side of the valve. A poor LM of $P$. hauckianum can be found in DwIVEDI \& MisRA (2014; pl. 2, fig. 11). A SV of a taxon presented as $P$. cf. hauckianum in KeLLY et al. (2005) http://craticula.ncl.ac.uk/EADiatomKey/html/ Planothidium.html has features very close to those of our new taxon (with the characteristic shadows on the sternum, see above). 'Achnanthes hauckiana GRUNOW, var. elliptica SCHULZ-DANZIG, fo. fossilis nov. fo.' is illustrated by MANGUIN (1952; fig. 29, reproduced in Fig. 28 ). The latter has a wide SV sternum and a RV with a small central area that may be close to our new taxon, but its flattened apices are quite different from those of Planothidium juandenovense. SEM examination of the type of Manguin's taxon would elucidate its true structure (particularly the stria structure). P. holstii (CLEVE) LANGE-Bert. (Basionym Achnanthes holstii Cleve 1881; 13, pl. 16: figs 6-7, reproduced in Fig. 29) has some similarities with our new taxon, but the RV of $P$. holstii has a characteristic bow-tie central area, while the central area is reduced in P. juandenovense (Fig. 19). The RV striae in $P$. holstii are narrow, while quadriseriate in our new taxon. Furthermore, the SV sternum of $P$. holstii is lanceolate, narrowing into linear endings, contrary to what is observed in P. juandenovense. On the short SV mantle of $P$. holstii (as illustrated by OTU \& SPAULDING 2011 ) is a row of regular small areolae, while in our new taxon a crista marginalis delineates groups of areolae facing the striae (Fig. 9). We incidentally note that the specimens in OTU \& SPAULding (2011) have terminal raphe endings turned to opposite sides while they are turned to the same side in CLEVE (1881). P. lilljeborgei (Grunow) Witkowski, Lange-Bert. et Metzeltin (2000; pl. 51, figs 27-29) may also be close to our taxon, with a similar valve shape and SV sternum, but with a lower SV stria density. Furthermore, a taxon illustrated by LANGe-Bertalot \& Krammer (1989; SEM, pl. 78, figs 5-6; LM, pl. 87, figs 25-29) as 'Achnanthes species I aus Süd-Chile' has short multiseriate SV striae, but it has no crista marginalis and no vestigial structures on the SV sternum.

\section{Planothidium quarnerense and allied taxa}

Planothidium quarnerense (Basionym Raphoneis quarnerensis GRUNOw) and allied taxa, are also close to $P$. juandenovense. The original Latin description of Raphoneis quarnerensis GRUNOw 1862 is: Rhaphoneis minor late ovato lanceolata, apicibus obtusis, striis brevibus marginalibus $20-24$ in 0.001"' (= 7.9-9.4 striae in $10 \mu \mathrm{m})$, area media irregulariter et subtiliter punctata late lanceolata. Longit. 0.0008-0.0013"' (=20-33 $\mu \mathrm{m})$. Latid. 0.0005-0.0007"' (=12.7-18 $\mu \mathrm{m})$. Habitat in fundo maris adriatici. [Strandsand von Martinsica (i.e. Martinscia, Croatia), 2-4 Fuss tief, leg. Dr. Lorenz] pl. 7, fig. 24 a-c(b ?) (400/1), reproduced in Fig. 30. There is neither permanent type slide of Rhaphoneis quarnerensis GRUNOW in the GRUNOW-slide collection (W), nor raw type material for SEM examination.

The original illustrations of Rhaphoneis quarnerensis mention GRUNOW's number ' 505 ', and some sketches used for this publication are available in $\mathrm{W}$. These small drawings are not very instructive relative to the terminal raphe endings of the taxon, and fig. $24 \mathrm{~b}$ (in GRUNOw 1862, reproduced in Fig. 30b) may, as remarked by A. GRUNOw himself, equally well illustrate Dimeregramma gregoriana abundantly present in the sample. In Grunow's accession book the same locality (Strandsand von Martinsica) has been mentioned under Grunow no. 505. The examination of two slides covered with mica, from the ' 505 ' locality, in the GRUNOW capsule collection annotated Amphora grevilleana (W-1901/3921-3922), examined at x40, did not permit us to detail the terminal raphe endings of Cocconeis quarnerensis (Figs 37-40). A sketch (W-1901/3630), annotated with $C$. quarnerensis (with no. '869.b') illustrates terminal raphe endings as simple (reproduced in Fig. 31). On the other hand, the SEM examination of material from the broken slide ' 869 ' W-1901/3162 annotated with Navicula ovulum GRUNOW (as illustrated in SchmidT 1874; 88, pl. 2, fig. 12, reproduced in Fig. 32), allows us to conclude that the latter is a Planothidium (Figs 41-42). It can be incidentally noted that the original illustration of Navicula ovulum GRUNOW (1860; pl. 1, fig. 19, reproduced in Fig. 33) is quite different from the one produced in SCHMIDT (1874; pl. 2, fig. 12, reproduced in Fig. 32). The Grunow material ('869' W-1901/3162) also contained an SV [probably mentioned as Raphoneis quarnerensis(?) in the accession book] with short pluriseriate striae (Fig. 43), no crista marginalis (Fig. 43 arrowhead) and a large elliptic sternum with vermiform structures (Fig. 44 arrow).

Navicula ovulum is recognized as a heterotypic synonym of Cocconeis quarnerensis GRUNOw in SCHMIDT (1874; 93, pl. 3, fig. 15-16, reproduced in Fig. 34). In the original illustration of C. quarnerensis (Fig. 34), the 
$\mathrm{RV}$ is broken (central area unreadable, Fig. 34 right) and the SV sternum is ornamented with granulations, while in HuSTEDT (1931-1959; fig. 814, surprisingly annotated as 'original'), the RV central area is large and circular, very similar to the illustration of Navicula ovulum (Fig. 32). In previous illustrations by GRUNOW (see $C$. quarnerensis sketch in GRUNOw's 'Bilder-Sammlung', W-1901/3630, reproduced in Fig. 31) and in SCHMIDT (1874-1959; pl. 192, figs 20-24), the RV central area is almost absent, the SV striae are very short and regular, with granular ornamentation on the large and elliptical SV sternum. Some other illustrations of C. quarnerensis GRUNOw were presented in SCHMIDT et al. (1874-1959; pl. 192, figs 20-24). WiTKOWSKI et al. (2000; pl. 55, figs $2-7$, no type checking), created the new combination Planothidium quarnerense (originally wrongly spelled P. quarnerensis), with the comment (but no illustration): 'apical endings unlike in Cocconeis terminate in polar position not below apices'.

Several illustrations assigned to Planothidium quarnerense (e.g. RIAUX-GoBIN 1991; pl. 4, figs 6-9; WiTKOWSKI et al. 2000; pl. 55, figs 2-7; SAR et al. 2003; fig. 43 and RiAUX-GoBIN et al. 2014; figs 15-20) show very short and regular SV striae and granular ornamentation on the large and elliptical SV sternum. In $P$. juandenovense, the SV striae are relatively long (Figs 8,10) and they often end irregularly (Fig. 2), furthermore the SV sternum is not regularly elliptical, but fusiform to rhombic, the SV striae being often shorter in mid-valve and longer on apices (Figs 2, 3-5, 13). In $P$. juandenovense, the SV sternum is ornamented with straight slits in the prolongation of each virga (Fig. 11 arrowhead). A main difference of $P$. juandenovense from Cocconeis (Planothidium) quarnerensis such as illustrated in RIAUX-GoBIN et al. 2014, from 'Arran57' slides, is the length of Planothidium quarnerensis three times higher (32.4-36.7 $\mu \mathrm{m}$, mean $34.3 \pm 1.5)$ and the lower stria densities (SV: 8.5-9 striae in $10 \mu \mathrm{m}$, mean 8.6 \pm .5 and RV: $9.5-10.5$ striae in $10 \mu \mathrm{m}$, mean $9.8 \pm 0.5$, Table 1). The measurements from the GrunOw's slides ' 505 ' (3921-3922 collection GRUNOW in W) confirm the latter points (Table 1).

From 1926 to 1980 , several varieties and formae of Planothidium quarnerense were published: Cocconeis quarnerensis f. rhomboidale ScHULZ-DANZIG (1926; 195, fig. 52), C. quarnerensis var. borgesensis J.N.MisRA (1956; 559, fig. 51), C. quarnerensis var. lanceolata JURILJ (1957; 68, pl. 16, fig. 4a,b,c, reproduced in Fig. 35) and C. quarnerensis f. rhombica GIFFEN (1980; 144, pl. 1, figs 13-14 reproduced in Fig. 36). Among the latter taxa, C. quarnerensis var. lanceolata might correspond to our taxon except for the valve shape (more acuminate than in $P$. juandenovense), the RV central area that is much more developed and the proximal raphe endings turn on the same side (while straight-coaxial in our taxon). On the other hand, the drawing of the SV in JURILJ (ref. cit.: middle illustration in Fig. 35), is very close to ours, with the characteristic vestigial and straight slits on the sternum. C. quarnerensis f. rhombica GIFFEN, except for its pot-bellied shape and tapered to capitate apices (versus oblong-elliptical with rounded apices in the new species), is close to our taxon. The SEM illustration (Figs 45-48) of the type material permits to transfer this taxon under Planothidium quarnerense $\mathrm{f}$. rhombica (GIFFEN) WITKOWSKI et RIAUX-GoB. comb. nov., due to its terminal raphe fissures characteristic of the genus (Fig. 48, arrowhead) and RV striae composed of multiple rows of areolae (Figs 47-48), while its shape, and slightly bigger dimensions, differentiate it from $P$. juandenovense (Table 1). The Fig. 45 permits description of the SVVC (sternum valve valvocopula) of $P$. quarnerense f. rhombica as large, with short-digit fimbriae (Fig. 45, arrowhead), and the RV central area as very restricted (Fig. 45). Unfortunately the SV of $P$. quarnerense f. rhombica was not found.

New combination: Planothidium quarnerense f. rhombica (GIFFEN) Witkowski et RiauX-Gob., Basionym: Cocconeis quarnerensis f. rhombica GIFFEN (1980; A checklist of marine littoral diatoms from Mahé, Seychelles Islands. Bacillaria 3; 129-159, p. 144, pl. 1, figs 13-14).

\section{Conclusion}

Planothidium quarnerense, Cocconeis quarnerensis var. lanceolata, P. quarnerense f. rhombica and P. juandenovense have similar morphometrics and features (Table 1). Nevertheless $P$. juandenovense is slightly smaller and has a RV and SV striation denser than other taxa. Furthermore, the SV crista marginalis and SV vestigial structures in P. juandenovense may be unique features. The SV sternum also shows different shape and width among all, and their biogeography also differs (Table 1). Planothidium juandenovense is morphologically close to $P$. delicatulum and $P$. septentrionale and probably belongs to the same morphological complex of species. The unique vestigial structures on the SV sternum may suggest that $P$. juandenovense has lost some ancestral characters and represents a recent splitting from the $P$. delicatulum group. Genetic analyses are needed to strengthen this hypothesis, but the new taxon is relatively rare and probably difficult to cultivate.

The Planothidium delicatulum complex is, however, a polymorphic group from which several varieties of the basionym Achnanthes delicatula were subsequently recombined and renamed as separate species (e.g., $A$. delicatula ssp. engelbrechtii (CHOLNOKY) LANGE-BERT., A. delicatula ssp. hauckiana, A. delicatula ssp. septentrionalis, A. delicatula var. robusta Hust., A. delicatula var. australis, see above). Furthermore, P. delicatulum var. delicatulum has to be lectotypified, which would allow description of its morphological characters. Comments by the 'Diatom Key Development Team' (KeLly et al. 2005; http://craticula.ncl.ac.uk/EADiatomKey/html/ Authors.html) are relevant about the need for caution 
related to the taxonomy of $P$. delicatulum, since the morphological characteristics of such a taxon depend on cell size (Tropper 1975; KocioleK \& StOERMER 2010).

\section{ACKNOWLEDGMENTS}

Yonko Gorand (C2M, University of Perpignan, France) is acknowledged for assistance with the SEM and Genowefa DANISZEWSKA-KowALCZYK (Palaeoceanology Unit, University of Szczecin, Szczecin, Poland) for LM material preparation. Many thanks are also due to Bart VAN DE ViJver (Botanic Garden Meise, Meise, Belgium) for observations and communications about KüTZING's possible original material of Achnanthes delicatula, Patrick Kociolek (MNH, Colorado State University at Boulder USA) for his helpful comments, Nadia ZoUAQ (Bibliothèque centrale du MNHN, Paris, France), Luc Ector [Luxembourg Institute of Science and Technology (LIST), Belvaux, Luxembourg] for their bibliographic help and Bernard BANAIGS (CRIOBE, PSL, USR 3278, CNRS-EPHE-UPVD) for his help with the chemical treatment of the GRUNOW's mica-slide sample. We acknowledge the constructive remarks by an anonymous reviewer. We also acknowledge the Terres Australes et Antarctiques Françaises (TAAF) who permitted the participation of C.R.-G. and A.W. to EPARSES 2009 expedition, the Polish grant No. 2012/04/A/ST10/00544 from the National Science Centre in Cracow and the CNRS-USR 3278-Labex CORAIL for supporting this research.

\section{REFERENCES}

Álvarez-Blanco, I. \& Blanco, S. (2013): Planothidium galaicum sp. nov. (Bacillariophyta, Achnanthidiaceae), a new diatom species from Galician coast, Spain. - Phytotaxa 151: 44-52.

ANONYMOUs (1975): Proposal for a standardization of diatom terminology and diagnoses. - Beihefte zur Nova Hedwigia 53: $323-354$

BĄK, M. \& LANGE-Bertalot, H. (2014): Four small-celled Planothidium species from Central Europe proposed as new to science. - Oceanological and Hydrobiological Studies 43: 346-359.

Bory de Saint-Vincent, J.B.G.M. (1822): Achnanthe. Achnanthes. - In: Dictionnaire Classique d'Histoire Naturelle. (Audouin, I. et al. eds), Vol. 1. - pp. 79-80, Paris, Rey et Gravier, Baudouin frères.

Bourrelly, P. \& Manguin, E. (1954): Contribution à la flore algale d'eau douce des Îles Kerguelen. - Mémoires de 1'Institut Scientifique de Madagascar, séries B, Biologique Végétale 5: 5-58.

BukhtiYARova, L.N. (2006): Additional data on the diatom genus Karayevia and a proposal to reject the genus Kolbesia. Beihefte zur Nova Hedwigia 130: 85-96.

Bukhtiyarova, L. \& Round, F.E. (1996): Revision of the genus Achnanthes sensu lato section Marginulatae Bukh. sect. nov. of Achnanthidium Kütz. - Diatom Research 11: 1-30.

Cleve, P.T. (1881): Färskvattens-Diatomacéer från Grönland och Argentinska Republiken. - Öfversigt af Kongliga Svenska Vetenskaps-Akademiens Förhandlingar 38: 3-13, pl. 36.

Cleve, P.T. \& Grunow, A. (1880): Beiträge zur Kenntniss der arktischen Diatomeen. - Kongl. Svenska Vetensk.-Akad. Handl. Ser. 4, 17: 1-121, pls I-VII.

Compère, P. \& VAN DE ViJVER, B. (2009): Planothidium engelbrechtii (Cholnoky) Round \& Bukhtiyarova; identity and lectotypification. - Fottea 9: 187-192.

Czarnecki, D.B. (1994): Nomenclatural changes for some diatoms found in Iowa. - Journal of the Iowa Academy of Science 101: 96-97.

Desrosiers, C.; Witkowski, A.; RiauX-Gobin, C.; Zglobicka, I.; Kurzydlowski, K. J.; Eulin, A.; Leflaive, J. \& TeN-Hage,
L. (2014): Madinithidium gen. nov. (Bacillariophyceae), a new monoraphid diatom genus from the tropical marine coastal zone. - Phycologia 53: 583-592.

DwiVEDi, R.K. \& MisRA, P.K. (2014): On the occurrence of freshwater diatoms of Southern Himachal Pradesh, India. - Phykos 44: 17-24

GIFFEN, M.H. (1980): A checklist of marine littoral diatoms from Mahé, Seychelles Islands. - Bacillaria 3: 129-159.

GrunOw, A. (1860): Über neue oder ungenügend gekannte Algen. - Verhandlungen der Kaiserlich-Königlichen ZoologischBotanischen Gesellschaft in Wien 10: 503, 5 pl.

Grunow, A. (1862): Die Österreichischen Diatomaceen nebst Anschluss einiger neuen Arten von andern Lokalitäten und einer kritischen Übersicht der bisher bekannten Gattungen und Arten. - Verhandlungen der KaiserlichKöniglichen Zoologisch-Botanischen Gesellschaft in Wien 12: 315-472, 545-588.

Hustedt, F. (1931-1959): Die Kieselalgen Deutschlands, Österreichs und der Schweiz. - In: Rabenhorst's Kryptogamenflora, Band 7, Teil 2. - 845 pp., Johnson Reprint, New York.

JuRILJ, A. (1957): Dijatomeje samatskog mora okoline Zagreba. (Flora of Diatoms of Sarmatic Sea in Environs of Zagreb). - Jugoslavenska Akademija Znanosti i Umjetnosi, Zagreb. (Acta Biologica 1) 28: 5-153.

Kelly, M.G.; Bennion, H.; Cox, E.J.; Goldsmith, B.; Jamieson, J.; Juggins, S.; Mann, D.G. \& Telford, R.J. (2005): Common freshwater diatoms of Britain and Ireland: an interactive key. - Environment Agency, Bristol. http:// craticula.ncl.ac.uk/EADiatomKey/html/Planothidium.html

Kociolek, J.P. \& STOERMER, E.F. (2010): Variation and polymorphism in diatoms: The triple helix of Development, genetics and environment. A review of the literature. - Vie et Milieu-Life and environment 60: 75-87.

KützING, F.T. (1844): Die Kieselschaligen Bacillarien oder Diatomeen. - pp. [i-vii], [1]-152, pls 1-30, Nordhausen: zu finden bei W. Köhne.

Lange-Bertalot, H. (1997): Zur Revision der Gattung Achnanthes sensu lato (Bacillariophyceae): Achnantheiopsis, eine neue Gattung mit dem Typus generis $A$. lanceolata. Revision of the Genus Achnanthes sensu lato (Bacillariophyceae): Achnantheiopsis, a New Genus with the Type Species $A$. lanceolata. - Archiv fur Protistenkunde 148: 199-208.

Lange-Bertalot, H. \& Krammer, K. (1989): Achnanthes, eine Monographie der Gattung mit Definition der Gattung Cocconeis und Nachträgen zu den Naviculaceae. Bibliotheca Diatomologica 18: 1-393.

Lange-Bertalot, H. \& RupPel, M. (1980): Zur Revision taxonomisch problematischer, ökologisch jedoch wichtiger Sippen der Gattung Achnanthes Bory. - Algological Studies 26: 1-31.

LE COHU, R. (2005): Révision des principales espèces dulçaquicoles d'Achnanthales (Bacillariophyta) des îles subantarctiques de Kerguelen. Revision of the main freshwater species of Achnanthales (Bacillariophyta) from sub-antarctic Iles Kerguelen. - Archiv für Hydrobiologie, Supplement 157/ Algological Studies 116: 79-114.

MANGUIN, E. (1952): Les diatomées fossiles du bassin thermo-minéral d'Antsirabé Ranomafana II. - Mémoires de l'Institut Scientifique de Madagascar 4: 1-57.

McNeill, J.; Barrie, F.R.; Buck, W.R.; Demoulin, V.; Greuter, W.; Hawksworth, D.L.; Herendeen, P.S.; KnapP, S.; Marhold, K.; Prado, J.; Prud'homme Van Reine, W.F.; Smith, G.F.; Wiersema, J.H. \& Turland, N. (eds \& Comps.) (2012): International Code of Nomenclature for algae, fungi, and plants (Melbourne Code), adopted by the Eighteenth International Botanical Congress Melbourne, Australia, July 2011. - 140 pp., Koeltz Scientific Books, Königstein.

MisRA, J.N. (1956): Systematic account of some littoral Marine Diatoms from the West Coast of India. - The Journal of 
the Bombay Natural History Society 53: 537-568.

Monnier, O.; LANGe-Bertalot, H.; Hoffmann, L. \& ECtor, L. (2007): The genera Achnanthidium Kützing and Psammothidium Bukhtiyarova et Round in the family Achnanthidiaceae (Bacillariophyceae): a reappraisal of the differential criteria. - Cryptogamie, Algologie 28: 141-158.

Morales, E.A. (2006): Small Planothidium Round et Bukhtiyarova (Bacillariophyceae) taxa related to P. daui (Foged) LangeBertalot from the United States. - Diatom Research 21: 325-342.

Otu, M. \& Spaulding, S. (2011): Planothidium holstii. - In: Diatoms of the United States. Retrieved January 14, 2016, from http://westerndiatoms.colorado.edu/taxa/species/ planothidium_holstii

Potapova, M. (2011): Platessa hustedtii. - In: Diatoms of the United States. http://westerndiatoms.colorado.edu/taxa/ species/platessa hustedtii

Riaux-Gobin, C. (1991): Diatomées d'une vasière intertidale du Nord Finistère (Dourduff) : genres Cocconeis, Campyloneis, Delphineis, Mastogloia et Raphoneis. - Diatom Research 6: $125-135$

RiauX-Gobin, C.; Compère, P.; Al-Handal, A.Y. \& Straub, F. (2012b): SEM survey of some small-sized Planothidium (Bacillariophyta) from coral sands off Mascarenes (Western Indian Ocean). - Nova Hedwigia, Beiheft 141: 295-314.

RiauX-Gobin, C.; Compère, P. \& Ector, L. (2014): Some Cocconeis species (Bacillariophyceaea) originally described by William Gregory and Robert Kaye Greville from the Firth of Clyde and Loch Fyne (Scotland). - Nova Hedwigia 99: 171-192.

RiauX-Gobin, C.; WitKowski, A. \& RupPel, M. (2012a): Scalariella a new genus of monoraphid diatom (Bacillariophyta) with a bipolar distribution. - Fottea 12: 13-25.

RiauX-Gobin, C.; Witkowski, A. \& Compère, P. (2010): SEM survey and taxonomic position of small-sized Achnanthidium (Bacillariophyceae) from coral sands off Réunion Island (Western Indian Ocean). - Vie et Milieu-Life and environment 60: 157-172.

RiauX-Gobin, C.; Romero, O.E.; Compère, P. \& Al-Handal, A.Y. (2011): Small-sized Achnanthales (Bacillariophyta) from coral sands off Mascarenes (Western Indian Ocean). Bibliotheca Diatomologica 57. - 234 pp., 88 pl., Cramer Verlag, Stuttgart.

RiauX-Gobin, C.; Romero, O.E.; Coste, M. \& Galzin, R. (2013): A new Cocconeis (Bacillariophyceae) from Moorea Island, Society Archipelago, South Pacific Ocean with distinctive valvocopula morphology and linking system. Botanica Marina 56: 339-356. http://dx.doi.org/10.1515/ bot-2012-0162

Ross, R.; Cox, E.J.; Karayeva, N.I.; ManN, D.G.; Paddock, T.B.B.; SimOnSEN, R. \& Sims, P.A. (1979): An amended terminology for the siliceous components of the diatom cell. - Beihefte zur Nova Hedwigia 64: 513-533.

Round, F.E. \& BAsson, P.W. (1997): A new monoraphid diatom genus (Pogoneis) from Bahrain and the transfer of previously described species $A$. hungarica and $A$. taeniata to new genera. - Diatom Research 12: 71-81

Round, F.E. \& BuKhTYAROva, L. (1996): Four new genera based on Achnanthes (Achnanthidium) together with a re-definition of Achnanthidium. - Diatom Research 11: 345-361.

Round, F.E.; Crawford, R.M. \& MANn, D.G. (1990): The Diatoms: Biology and morphology of the genera. -747 pp., Cambridge University Press, Cambridge.

Rovira, L.; Witkowski, A; Trobajo, R.; RuPPel, M. \& IBANEZ, C. (2011): Planothidium iberense sp. nov., a new brackish diatom of the Ebro estuary, northeast Spain. - Diatom Research 26: 99-107.

Rumrich, U.; Lange-Bertalot, H. \& Rumrich, M. (2000): Diatomeen der Anden. Von Venezuela bis Patagonien/ Feuerland. - In: LANGE-BERTALOT, H. (ed.): Iconographia Diatomologica, Vol. 9. - 649 pp., A.R.G. Gantner Verlag K.G., Koeltz Scientific Books, Konigstein, Germany.

SAR, E.A.; Romero, O.E. \& Sunesen, I. (2003): Cocconeis Ehrenberg and Psammococconeis Garcia (Bacillariophyta) from the Gulf of San Matías, Patagonia, Argentina. - Diatom Research 18: 79-106.

Schmidt, A. (1874): Die in den Grundproben der Nordseefahrt vom 21 Juli bis 9. Sept. 1872 enthaltenen Diatomeen. - Jahresbericht der Commission zur wissenschaftlichen Untersuchung der deutschen Meere in Kiel.

Schmid, A. et al. (1874-1959): Atlas der Diatomaceenkunde. Heft 1-120, Tafeln 1-460. Aschersleben, Leipzig.

Simonsen, R. (1987): Atlas and Catalogue of the Diatom Types of Friedrich Hustedt, Vol. 2. - plates 1-395, J. Cramer, Berlin.

Schulz, P. (1926): Die Kieselalgen der Danziger Bucht mit Einschluss derjenigen aus glazialen und postglazialen Sedimenten. Botanisches Archiv. Konigsberg 13: 149-327.

Tropper, C.B. (1975): Morphological variation of Achnanthes hauckiana (Bacillariophyceae) in the field. - Journal of Phycology 11: 297-302.

Van de Vijver, B.; Wetzel, C.; Kopalová, K.; Zidarova, R. \& Ector, L. (2013): Analysis of the type material of Achnanthidium lanceolatum Brébisson ex. Kützing (Bacillariophyta) with the description of two new Planothidium species from the Antarctic Region. - Fottea 13: 105-117.

Van Heurck, H. (1880-1885): Synopsis des Diatomées de Belgique. - Texte: 235+120 pp., Atlas: 132 pl. Van Heurck, Anvers; Ducaju et Cie.

Wetzel, C.E. \& Ector, L. (2014): Taxonomy, distribution and autecology of Planothidium bagualensis sp. nov. (Bacillariophyta) a common monoraphid species from southern Brazilian rivers. - Phytotaxa 156: 201-210.

Witkowski, A. (1998): Marine Taxa. - In: Moser, G.; LangeBertalot, H. \& Metzeltin, D. (eds): Inselder Endemiten. Geobotanisches Phänomen Neukaledonien. - Bibliotheca Diatomologica 38: 347-381.

Witkowski, A.; Lange-Bertalot, H. \& Metzeltin, D. (2000): Diatom flora of marine coasts I. - In: LANGE-BERTALOT, H. (ed.): Iconographia Diatomologica. Annotated Diatom Micrographs. Diversity-Taxonomy-Identification, Vol. 7. - 925 pp., A.R.G. Gantner Verlag K.G., Ruggell.

(C) Czech Phycological Society (2018)

Received April 11, 2017

Accepted July 24, 2017 